\title{
IODP Expedition 319, NanTroSEIZE Stage 2: First IODP Riser Drilling Operations and Observatory Installation Towards Understanding Subduction Zone Seismogenesis
}

\author{
by Lisa McNeill, Demian Saffer, Tim Byrne, Eiichiro Araki, Sean Toczko, \\ Nobu Eguchi, Kyoma Takahashi, and IODP Expedition 319 Scientists
}

doi: 10.2204/iodp.sd.10.01.2010

\begin{abstract}
The Nankai Trough Seismogenic Zone Experiment (NanTroSEIZE) is a major drilling project designed to investigate fault mechanics and the seismogenic behavior of subduction zone plate boundaries. Expedition 319 is the first riser drilling operation within scientific ocean drilling. Operations included riser drilling at Site C0009 in the forearc basin above the plate boundary fault, non-riser drilling at Site C0010 across the shallow part of the megasplay fault system-which may slip during plate boundary earthquakes - and initial drilling at Site C0011 (incoming oceanic plate) for Expedition 322. At Site C0009, new methods were tested, including analysis of drill mud cuttings and gas, and in situ measurements of stress, pore pressure, and permeability. These results, in conjunction with earlier drilling, will provide a) the history of forearc basin development (including links to growth of the megasplay fault system and modern prism), b) the first in situ hydrological measurements of the plate boundary hanging wall, and c) integration of in situ stress measurements (orientation and magnitude)
\end{abstract}

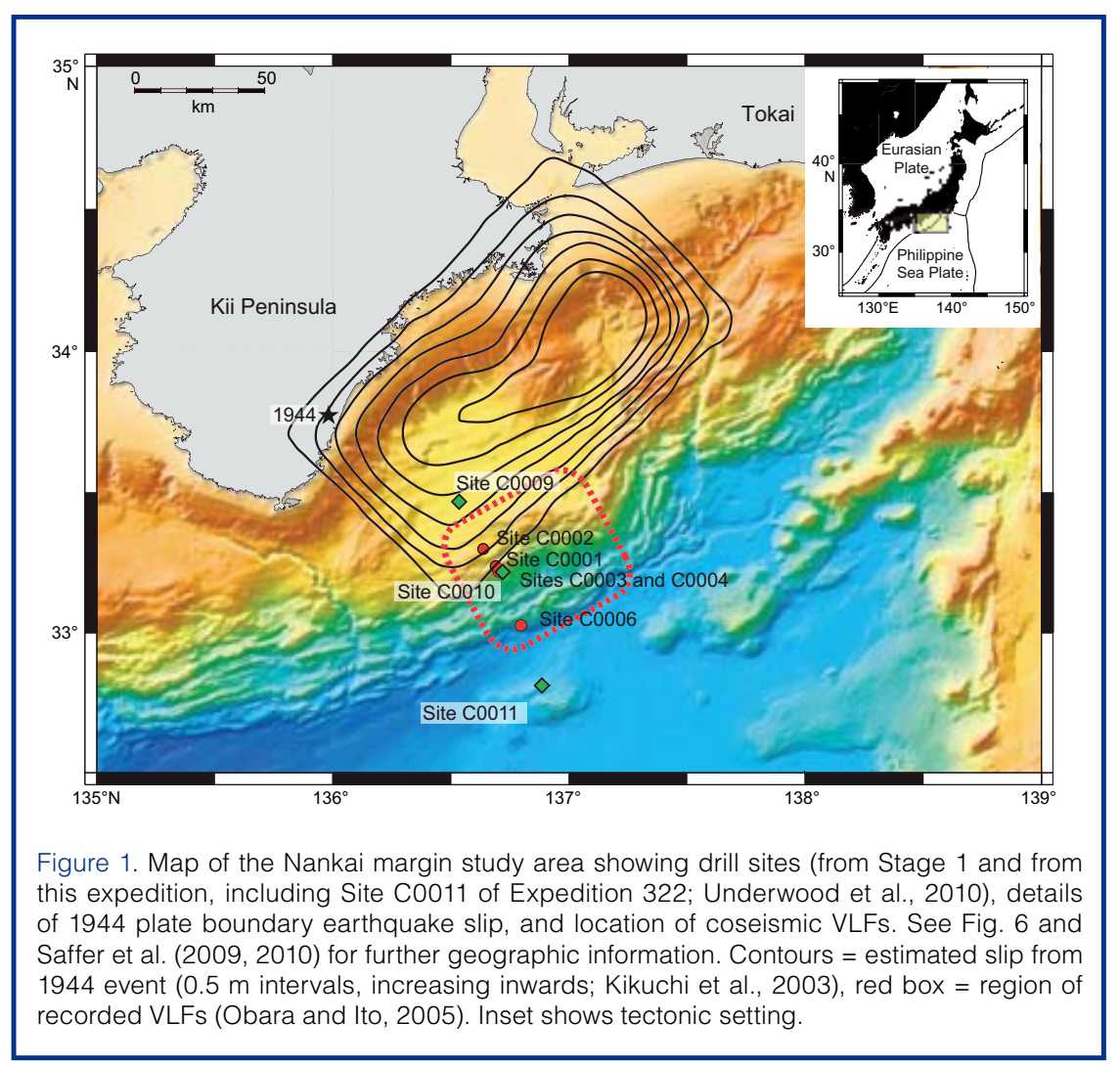

across the forearc and with depth. A vertical seismic profile (VSP) experiment provides improved constraints on the deeper structure of the subduction zone. At Site C0010, logging-while-drilling measurements indicate significant changes in fault zone and hanging wall properties over short $(<5 \mathrm{~km})$ along-strike distances, suggesting different burial and/or uplift history. The first borehole observatory instruments were installed at Site C0010 to monitor pressure and temperature within the megasplay fault zone, and methods of deployment of more complex observatory instruments were tested for future operations.

\section{Introduction}

Subduction zones account for 90\% of global seismic moment release, generating damaging earthquakes and tsunamis with potentially disastrous effects as exemplified by recent earthquakes in Indonesia and Chile. Understanding the processes that govern the strength and nature of slip along these plate boundary fault systems by direct sampling and measurement of in situ conditions is a crucial step toward evaluating earthquake and tsunami hazards. To this end, the Integrated Ocean Drilling Program (IODP) Nankai Trough Seismogenic Zone Experiment (NanTroSEIZE) project (Tobin and Kinoshita, 2006) has been implemented, complementing other fault drilling projects worldwide (e.g., the San Andreas Fault Observatory at Depth (SAFOD) and the Taiwan-Chelungpu Drilling Project). NanTroSEIZE is a multistage program focused on understanding the mechanics of seismogenesis and rupture propagation along subduction plate boundary faults, targeting a transect of the Nankai margin offshore the Kii Peninsula, the location of the 1944 M 8.2 Tonankai earthquake (Fig. 1). The drilling program is a coordinated effort over a period of years to characterize, sample, and instrument the plate boundary system at several locations, culminating in drilling, sampling, and instrumenting the plate boundary fault near the updip limit of inferred coseismic slip, at $\sim 6-7 \mathrm{~km}$ below sea- 


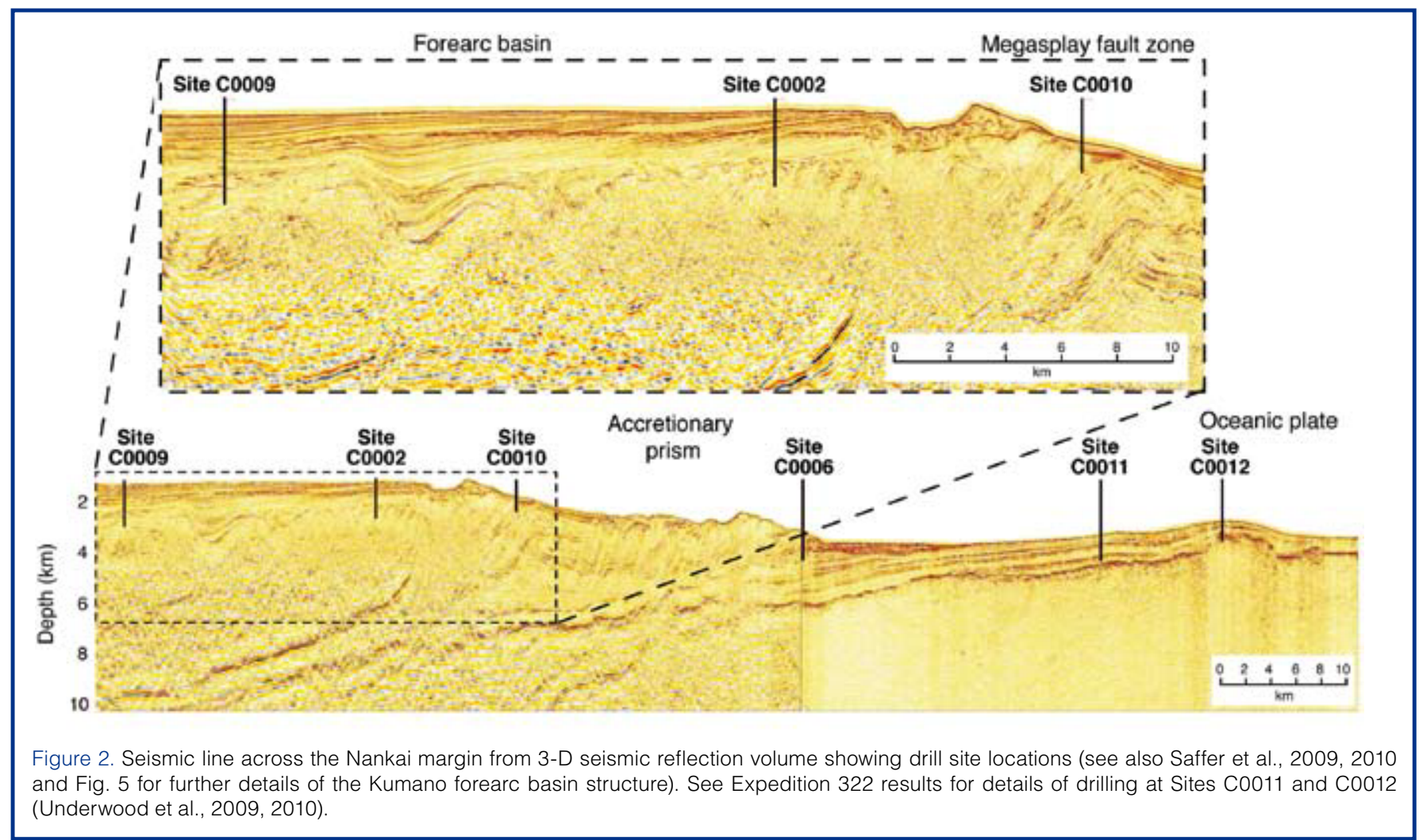

floor (Tobin and Kinoshita, 2006). The main project objectives are to understand the following:

- In situ physical conditions and the state of stress within different parts of the subduction system during an earthquake cycle

- The mechanisms controlling the updip aseismic-seismic transition along the plate boundary fault system

- Processes of earthquake and tsunami generation and strain accumulation and release

- The mechanical strength of the plate boundary fault

- The potential role of a major fault system (termed the "megasplay" fault, Fig. 2) in accommodating earthquake slip and hence influencing tsunami generation

These objectives are being addressed through a combined program of non-riser and riser drilling and integration of linked long-term observatory, geophysical, laboratory, and numerical modeling efforts.

\section{The Nankai Margin}

The Nankai subduction zone forms as a result of subduction of the Philippine Sea Plate beneath the Eurasian Plate at $40-65 \mathrm{~mm} \mathrm{yr}^{-1}$ (Seno et al., 1993; Miyazaki and Heki, 2001; Fig. 1) and has generated M8 tsunamigenic earthquakes on identifiable segments of the margin regularly ( 150-200 years) over at least the past $\sim 1000-1500$ years (Ando, 1975). The most recent earthquakes occurred in 1944 (Tonankai M 8.2) and 1946 (Nankaido M 8.3). The margin has been extensively studied using marine geophysics (including two 3-D multichannel seismic reflection volumes), ocean drilling (across three transects along the margin), passive seismology, and geodesy. The position and effects of earthquake rupture are therefore relatively well understood, and the structure of the margin is well imaged. More recently, very low frequency (VLF) earthquakes and slow slip events have also been recorded, in the shallowest and deeper parts of the subduction system, respectively (Obara and Ito, 2005; Ito et al., 2007). The region offshore the Kii peninsula is the focus of the NanTroSEIZE experiment drilling transect and marks the western end of the 1944 earthquake rupture zone (Fig. 1). The drilling transect region has been imaged with an $\sim 11 \mathrm{~km} \times 55 \mathrm{~km}$ 3-D seismic reflection volume (Moore et al., 2007, 2009; Bangs et al., 2009; Park et al., 2010) revealing along-strike structural variability in addition to excellent across-strike imagery. This region is also the focus of the seafloor observatory project "Dense Oceanfloor Network System for Earthquakes and Tsunamis" (DONET; http:// www.jamstec.go.jp/jamstec-e/maritec/donet/) which will install seafloor instruments as part of a cabled network connected to shore. This observatory network will also connect to borehole observatory instruments installed as part of the NanTroSEIZE project (Tobin and Kinoshita, 2006) to enable longer term monitoring of seismicity, deformation, hydrological transients, pressure, and temperature.

\section{The NanTroSEIZE Project and Expedition 319}

Shallow drilling of a series of holes across the forearc was conducted successfully during Stage 1 of the NanTroSEIZE project in late 2007 through early 2008 onboard the $\mathrm{D} / \mathrm{V}$ Chikyu (Expeditions 314, 315, 316; Ashi et al., 2009; Kimura et al., 2009; Kinoshita et al., 2009a; Fig. 1). These expedi- 
tions collected logging-while-drilling (LWD) data (providing in situ measurements of physical properties and stress state) and core samples in the shallower aseismic regions of the frontal thrust and the major megasplay fault, and within the forearc basin. Stage 2 consisted of Expedition 319 (the subject of this report) and Expedition 322, conducted from May to October 2009. Expedition 322 drilled, logged, and sampled the input sedimentary section to characterize the properties of sediment that ultimately influence fault development and seismogenic behavior (Underwood et al., 2009, 2010).

Expedition 319 drilled two main sites, C0009 and C0010 (Figs. 1 and 2). Drilling operations were also started at Site C0011, contributing to Expedition 322 . Site C0009 is located within the central Kumano forearc basin in the hanging wall of the locked seismogenically active plate boundary (Figs. 1 and 2) and is the site for a future long-term observatory site. Objectives were to drill, sample (cuttings and cores), and log (wireline log data) the hole, conduct downhole in situ measurements and a vertical seismic profile (VSP) experiment, and finally case and cement the hole for future observatory installation. The scientific objectives at Site C0009 were as follows: (1) document the lithology, structure, in situ properties and development of the central Kumano forearc basin (lying within the hanging wall of the seismogenic plate boundary fault); (2) collect core samples at the depth of a future potential observatory for geotechnical analysis in advance of observatory instrument installation; and (3) constrain the seismic properties of the deeper subduction zone including the plate boundary below the drill site using a two-ship VSP experiment.

Site C0010 is located $\sim 3.5 \mathrm{~km}$ along strike from Site C0004 (Fig. 1, see also Fig. 6 and Saffer et al., 2010) which was drilled during Expeditions 314 and 316 (Kinoshita et al., 2009a; Kimura et al., 2009). Objectives were to drill and log the hole, install an instrument package across the fault zone (designed to collect data for a few years), and prepare for the future installation of an observatory by conducting a “dummy" run of an instrument package containing a strainmeter and seismometer. Logging data at this site included measurement-while-drilling (MWD) and LWD (gamma ray, resistivity-at-bit, and resistivity image data); these data were used to constrain the lithology, structural deformation, and in situ stress within and across the shallow section of the megasplay fault zone (Figs. 1 and 2). This site provides the opportunity to document and quantify the degree of along-strike structural variability within the megasplay fault system through comparison with Site C0004.

Expedition 319 was noteworthy because it included the first riser drilling operations in scientific ocean drilling history, as well as the first observatory installations conducted

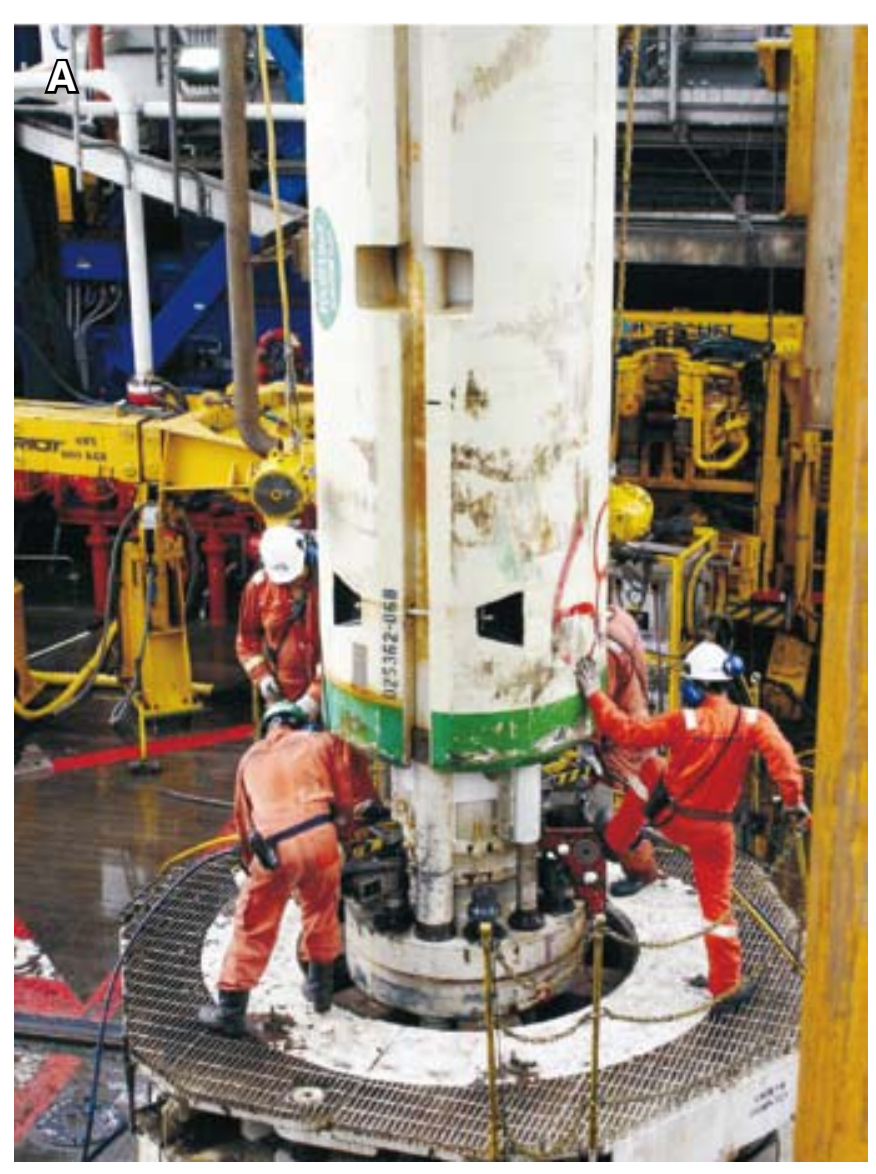

Figure 3. Drilling tools and operations: [A] riser drilling, [B] Modular Formation Dynamics Tester wireline logging tool (single probe at top, dual packer below), [C] observatory dummy run instruments.
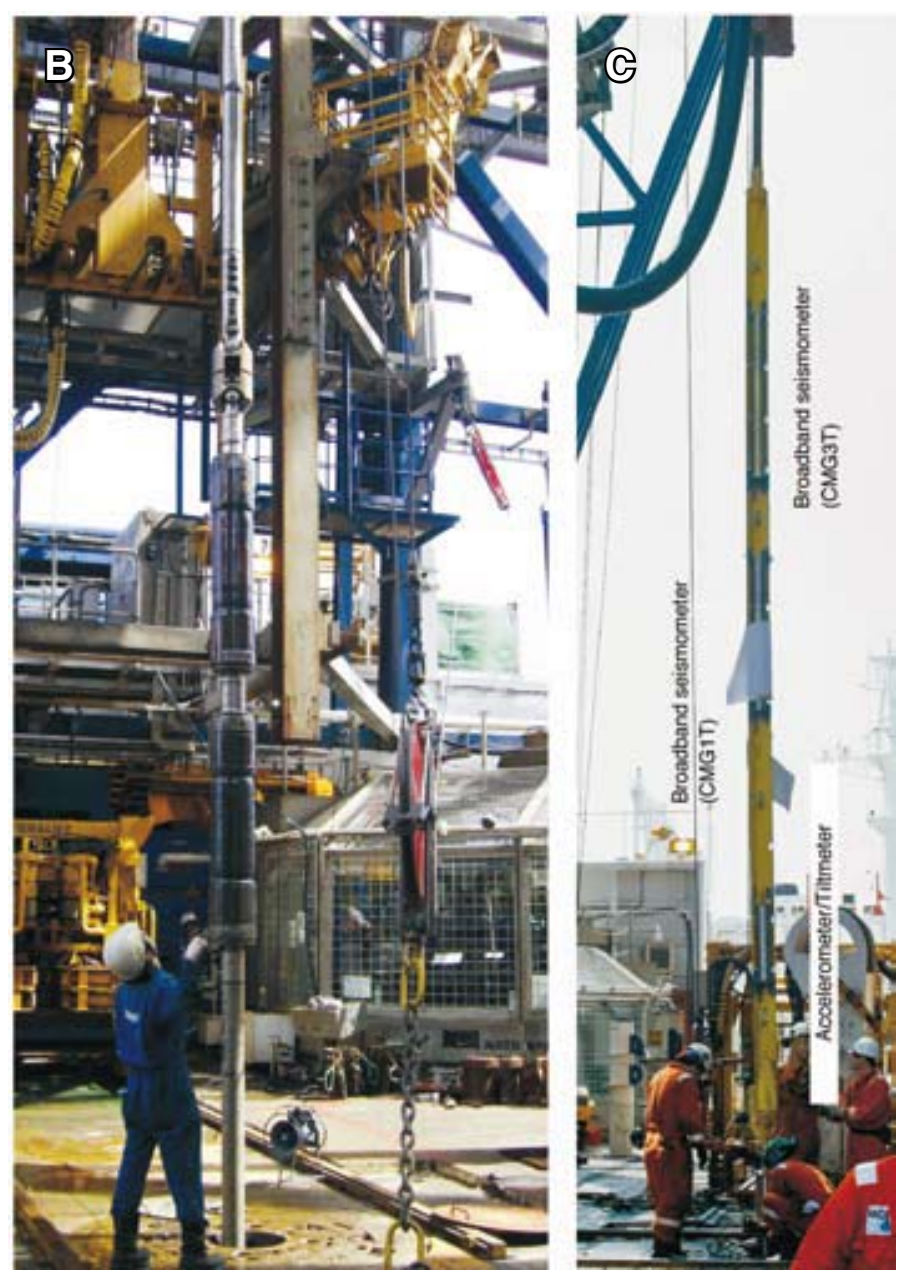


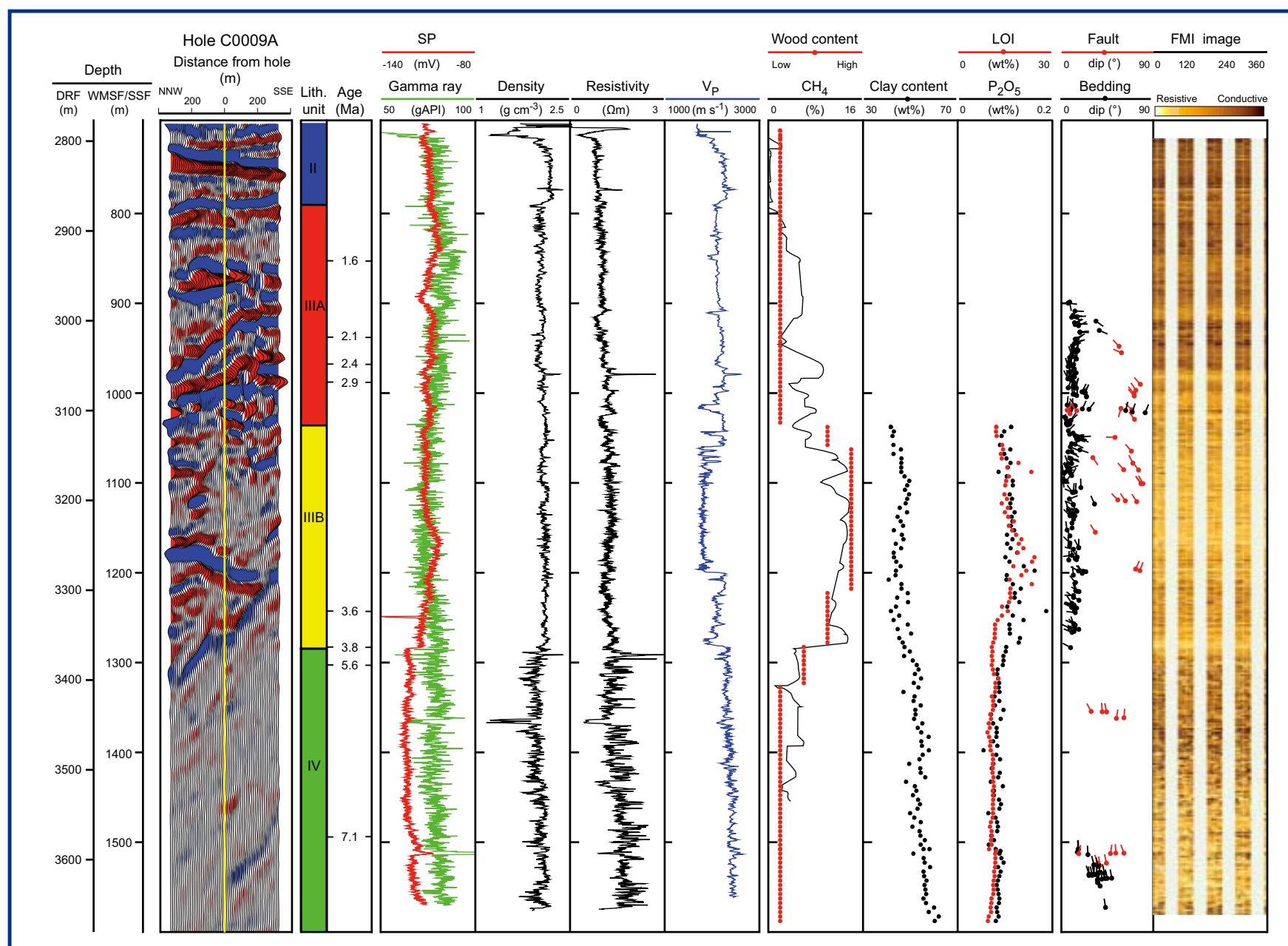

Figure 4. Site summary diagram for Site C0009 within the central forearc basin and hanging wall of the seismogenic plate boundary fault, showing wireline logs and cuttings data from $~ 700$ mbsf to 1600 mbsf. SP=spontaneous potential, LOI=Ioss on ignition, FMI=Formation Microlmager (resistivity image).

by the D/V Chikyu (Saffer et al., 2009). Riser drilling (Fig. 3A) enabled several significant measurements new to IODP, including measurement of in situ stress magnitude and pore pressure using the Modular Formation Dynamics Tester (MDT) wireline tool (Fig. 3B), real-time mud gas analysis, and the analysis of drill cuttings. These types of measurements are critical for addressing the scientific objectives of the NanTroSEIZE project and will be utilized in future riser drilling operations targeting the deeper seismogenic portions of the plate boundary and megasplay fault systems. Data collected from the long offset 'walkaway' VSP experiment will allow remote imaging and resolution of properties of the deeper plate boundary fault system. The first observatory instruments of the NanTroSEIZE experiment were installed during Expedition 319, in the form of a simple instrument package (termed a "smart plug") at Site C0010, where it was designed to monitor pressure and temperature at the shallow megasplay fault (Araki et al., 2009; Saffer et al., 2009).

\section{Site C0009}

All of the primary planned scientific objectives were achieved through successful drilling operations at this site. Riserless drilling, with gamma ray logging data, and casing to 703.9 mbsf were followed by preparations for riser drilling of the deeper hole. Prior to riser drilling, a Leak-Off Test (LOT) was conducted for operational reasons, and it provided a measurement of minimum in situ stress magnitude. Riser drilling continued from 703.9 to a Total Depth (TD) of 1604 mbsf. Throughout riser operations, cuttings and mud gas were collected for analysis. From a depth of 1017 mbsf, cuttings were sufficiently cohesive to allow analyses of detailed lithology, bulk composition, and some structural and physical properties, in addition to lithology and biostratigraphic analysis of incohesive cuttings at shallower depths. Limited coring at the base of the hole (1510-1594 mbsf) allowed calibration of cutting measurements and log data as well as analysis of detailed lithology, structure, physical properties, and geochemistry. Cores will also provide material for shore-based geotechnical testing that will help in the design and engineering of the planned future borehole observatory at this site. Following riser drilling, three wireline runs from $\sim 705$ mbsf to TD collected a range of datasets within the riser hole, including density, resistivity image, caliper, and gamma ray logs. Cuttings and core samples and logs together provide information about stratigraphy, age, composition, physical properties, and structure of the forearc basin sediments and underlying material (Fig. 4). The third 


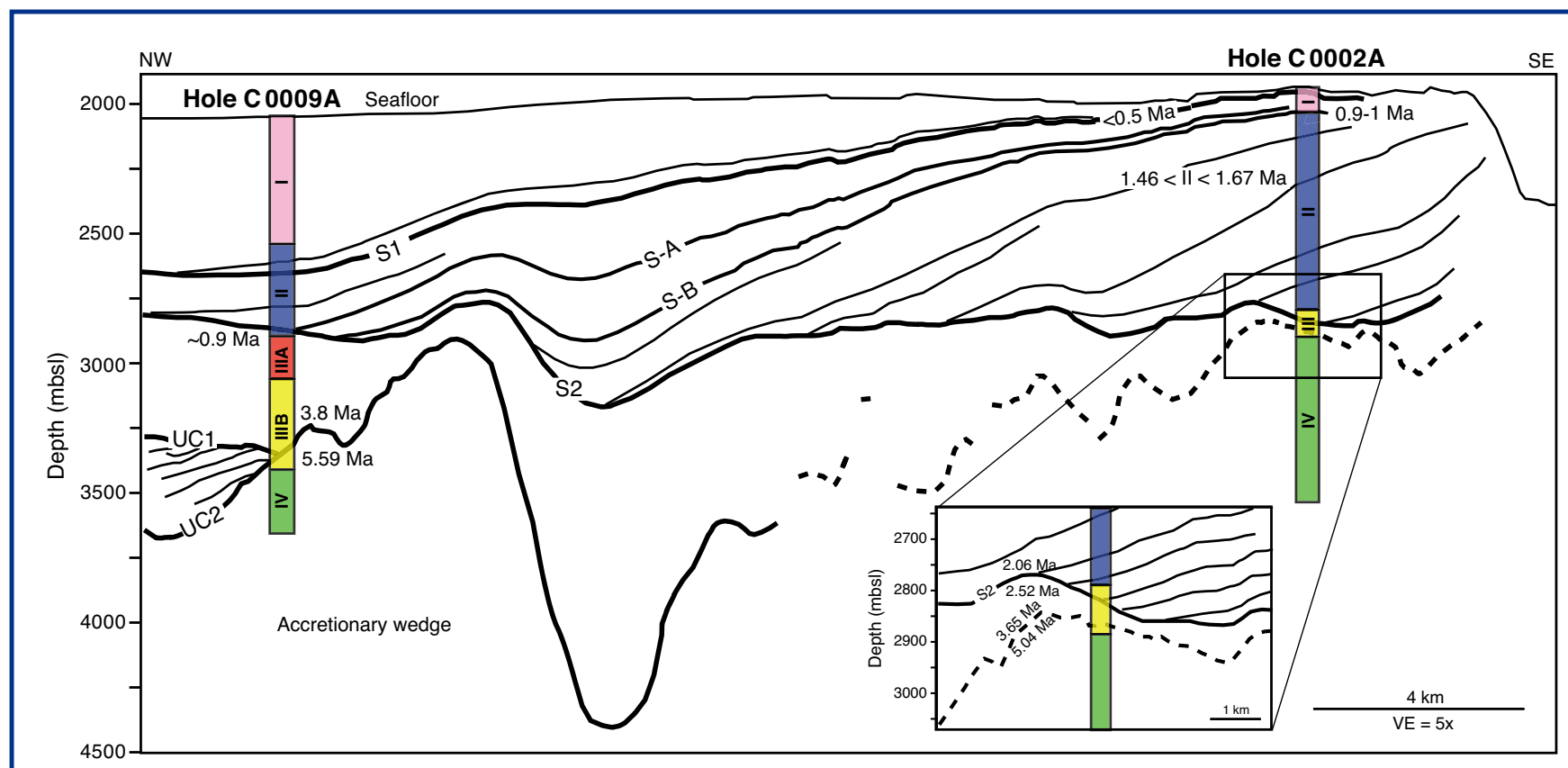

Figure 5. Interpretation of seismic line across the Kumano forearc basin including correlation between Sites C0009 (this expedition) and C0002 (Expeditions 314, 315; Kinoshita et al., 2009b) using seismic and borehole data. Lithologic units are shown at each site. Key regional seismic surfaces are also highlighted (UC1, UC2 = angular unconformities; S1, S2= regional seismic surfaces; S-A, S-B = representative correlatable surfaces within forearc basin stratigraphy). Inset shows detail of Units III-IV at Site C0002. See Saffer et al. (2009, 2010) for further details of seismic stratigraphy and structure.

wireline logging run utilized the MDT tool (Fig. 3B) to measure in situ stress magnitude, pore pressure, and permeability at multiple positions downhole between $\sim 700 \mathrm{mbsf}$ and 1600 mbsf. Following riser operations, the hole was cased and cemented in preparation for future observatory installation. The final operation at Site C0009 was a walkaway VSP experiment, conducted using the JAMSTEC vessel R/V Kairei, followed by a zero-offset VSP. For the walkaway VSP, the R/V Kairei fired airguns along a transect perpendicular to the margin (maximum offset $30 \mathrm{~km}$ ) and along a circular trackline around the vessel to a wireline array of seismometers within the borehole. Airguns onboard $\mathrm{D} / \mathrm{V}$ Chikyu were then fired and recorded on the borehole seismometer array for the zero offset VSP. These experiments together provide improved definition of velocity (and hence depth) and structure, including anisotropy, around the borehole and of the underlying plate boundary.

\section{Preliminary Results, Site C0009}

Combining cuttings, core data, and log data, four stratigraphic units were defined (Fig. 4). Units I and II (0-791 mbsf) are Quaternary forearc basin deposits characterized by mud interbedded with silt and sand, with shallower Unit I being relatively more sand rich. Plio-Pleistocene Unit III (silty mudstone with rare silty sand interbeds) is notable for its high wood/lignite and methane content from cuttings and from analysis of formation gases released and collected in the drill mud. These are particularly concentrated in the lower subunit (IIIB), which is defined by increased organic material (from wood chips, total organic carbon (TOC) and loss on ignition (LOI) concentrations), methane, and glauco- nite (Fig. 4). The molecular composition of methane suggests a microbial source, consistent with estimated temperature at the bottom of the hole $\left(\sim 50^{\circ} \mathrm{C}\right)$ and with an interpretation of gas generated in situ from terrestrially sourced organic matter. A major angular unconformity documented in both cuttings and $\log$ datasets and representing a hiatus of $\sim 1.8 \mathrm{Ma}$ is crossed at $1285 \mathrm{mbsf}$ and marks the Unit III-IV boundary (Fig. 4). This unconformity can be traced across the Kumano forearc basin (Fig. 5). The underlying unit (Unit IV) is composed of late Miocene silty mudstone with minor silt and vitric tuff turbiditic interbeds. All four units were deposited above the paleo CCD (at $\sim 4000 \mathrm{~m}$ depth today). The stratigraphic succession is interpreted as a series of relatively fine-grained forearc basin-filling mudstones and thin turbidites (Units I, II, and/or III) underlain by older forearc basin, slope deposits or accreted prism sediments (Units IV and/or III) (see Saffer et al., 2010 for further discussion of the origin of Unit IV). As part of future research, the drilling results from Site C0009, together with results from Stage 1, can be integrated with 3-D seismic reflection data to better understand the history of forearc basin development and its potential relationship to activity on the megasplay fault.

Structural interpretations of the forearc basin and underlying slope basin-prism units were derived primarily from log and cuttings data and by comparison with cores at the base of the hole. Many types of minor structures, including faults with measurable displacement, are identified in cores. However, deformation is markedly more subdued than within the accretionary prism sediments (Unit IV) at the base of Site $\mathrm{C} 0002$, close to the seaward edge of the forearc basin. 
Structures can also be identified and categorized in cuttings of $\sim 2 \mathrm{~cm}$ or larger diameter. This technique allowed the distribution of vein structures, associated with probable tectonic-induced dewatering, to be determined downhole. Wireline log Formation MicroImager (FMI) resistivity images and caliper data were used to identify the orientation of borehole enlargement, indicating the minimum horizontal stress orientation ("borehole breakouts"). These results allowed the in situ stress orientation to be determined (Lin et al., 2010), complementing measurements of in situ stress magnitude from other tools (see below) and in situ stress measurements at other sites across the margin (McNeill et al., 2004; Ienaga et al., 2006; Byrne et al., 2009). Minimum horizontal stress consistently trends NE-SW downhole ( 700-1600 mbsf); therefore, the maximum horizontal stress trends NW-SE (Fig. 6). This is similar to that observed in other boreholes across the accretionary prism and megasplay fault (TDs of $\sim 400-1000 \mathrm{mbsf}$ for NanTroSEIZE Stage 1 boreholes; see Kinoshita et al., $2009 \mathrm{~b}$ ), and is perpendicular to the margin and roughly parallel to the plate convergence direction (Fig. 6). This orientation, however, contrasts with that in the outer forearc basin, at Site C0002, where maximum horizontal stress is NE-SW. This Site C0002 orientation is consistent with mul- tiple lines of evidence for margin-normal extension, potentially driven by uplift and tilting of the seaward forearc basin.

Measurements of the physical properties of sediments and rocks (bulk density, P- and S-wave velocity, resistivity, porosity, magnetic susceptibility, and thermal conductivity) were derived from wireline logs and core and cuttings materials. Cuttings materials are likely to be affected by the drilling process and the time of exposure to drilling mud; therefore, physical properties and some geochemical measurements are likely to be compromised. In particular, porosity is overestimated and bulk density underestimated. Relative bulk compositions are subject to errors due to artifacts in carbonate content associated with the interaction between cuttings and the drilling mud. However, relative downhole trends may be valid. Log-derived P-wave velocity and Poisson's ratio are markedly reduced (Fig. 4) where methane gas concentrations are high (primarily in Unit IIIB), and preliminary calculations suggest a gas saturation of $\sim 10 \%$. Corrected velocities from these sonic logs and from the later VSP experiment (see below) were applied to the 3-D seismic reflection data at the borehole to allow integration of borehole and seismic datasets.

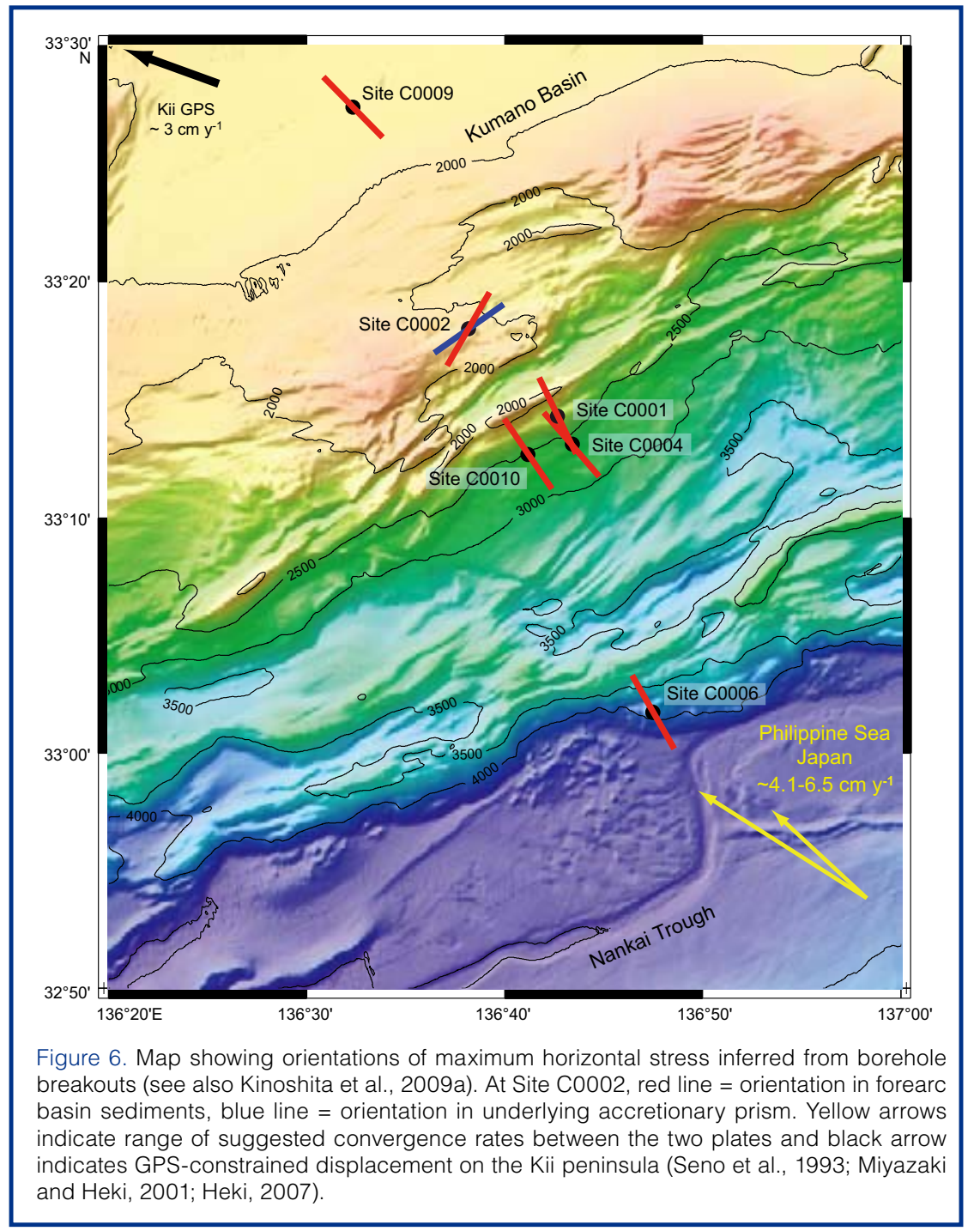

A series of new downhole measurements of least principal stress magnitude $\left(\sigma_{3}\right)$, pore pressure, and permeability were made using the MDT wireline logging tool (Fig. 3B) within the riser drilled section of the forearc basin and underlying sediments ( 700-1600 mbsf). This was the first time this tool was used in ocean drilling (its diameter prevents usage in IODP non-riser holes). The tool has two components: a single probe which makes discrete measurements of pore pressure and fluid mobility; and the dual packer which isolates an interval of the borehole (set at $1 \mathrm{~m}$ for Expedition 319) to measure pore pressure and fluid mobility during a drawdown test and stress magnitude by hydraulic fracturing. Nine single-probe measurements, one dual packer drawdown test, and two dual packer in situ stress magnitude tests were conducted at Site C0009. The pore pressure measurements indicate that formation pore pressure is hydrostatic or very slightly elevated to depths of at least 1460 mbsf. Permeabilities from the single probe range from $\sim 10^{-16} \mathrm{~m}^{2}$ to $10^{-14} \mathrm{~m}^{2}$, with variations that are generally consistent with lithology. Permeability from the drawdown test within the clay-rich Unit IV yielded slightly lower permeability of $1.3 \times 10^{-17} \mathrm{~m}^{2}$. However, the pore pressure and permeability measurements should be viewed with some caution, 
as the MDT tool is typically used in more permeable formations, and a long pressure recovery time is needed in the low permeability formations drilled here. Hydraulic fracturing tests were conducted at $\sim 870$ mbsf within the forearc basin sediments, and at 1460 mbsf near the bottom of the borehole within older forearc basin, slope deposits, or accreted sediments of the prism. The shallower test is thought to be reliable and can be compared with the leak-off test at a comparable depth ( 710 mbsf). Both tests suggest that $\sigma_{3}$ is $\sim 30-35 \mathrm{MPa}$ and horizontal (therefore the minimum horizontal stress).

The vertical seismic profiling experiment was conducted successfully and included a walkaway and zero offset component. For the walkaway experiment, a single $53.4-\mathrm{km}$ line perpendicular to the margin ( 880 shots) and a circular path of $3.5 \mathrm{~km}$ radius around the borehole (275 shots) were shot by the R/V Kairei. During the walkaway experiment, direct wave arrivals, refractions from the accretionary prism, and reflections from prism, megasplay fault, and plate boundary interfaces were recorded. These will provide information on seismic velocity (enabling deeper drilling targets to be determined), seismic properties, and structure of the deeper subduction zone. Anisotropy was observed during the circular transect, compatible with the in situ stress orientation measurements from logging results (Hino et al., 2009). The zero-offset experiment provided improved seismic velocity measurements around and immediately below the borehole, thus allowing the results from cores, cuttings, logs, and seismic data to be depth calibrated and integrated with confidence.

\section{Site C0010}

Operations at Site C0010 included running a minimal array of MWD/LWD logging tools (gamma ray, resistivity, including resistivity image) across the shallow megasplay fault system to a TD of 555 mbsf (Fig. 7), followed by casing of the hole, an observatory dummy run with a strainmeter and seismometer to test the impact of deployment on the instruments (Fig. 3C), and installation of a simple short-term observatory package ('smart plug') to measure temperature and pressure over a period of a few years (Fig. 8), which is a crucial component of the NanTroSEIZE experiment. The MWD/LWD data allow definition of the major lithologic units and identification of the megasplay fault zone and its properties. Comparison with Site C0004 (Kinoshita et al., $2009 b)$ reveals considerable differences in both hanging wall and fault zone properties over only $\sim 3.5 \mathrm{~km}$ along strike.

\section{Preliminary Results, Site C0010}

Three distinct lithologic units are defined at Site C0010 (Fig. 7) based on logging data and through comparison with

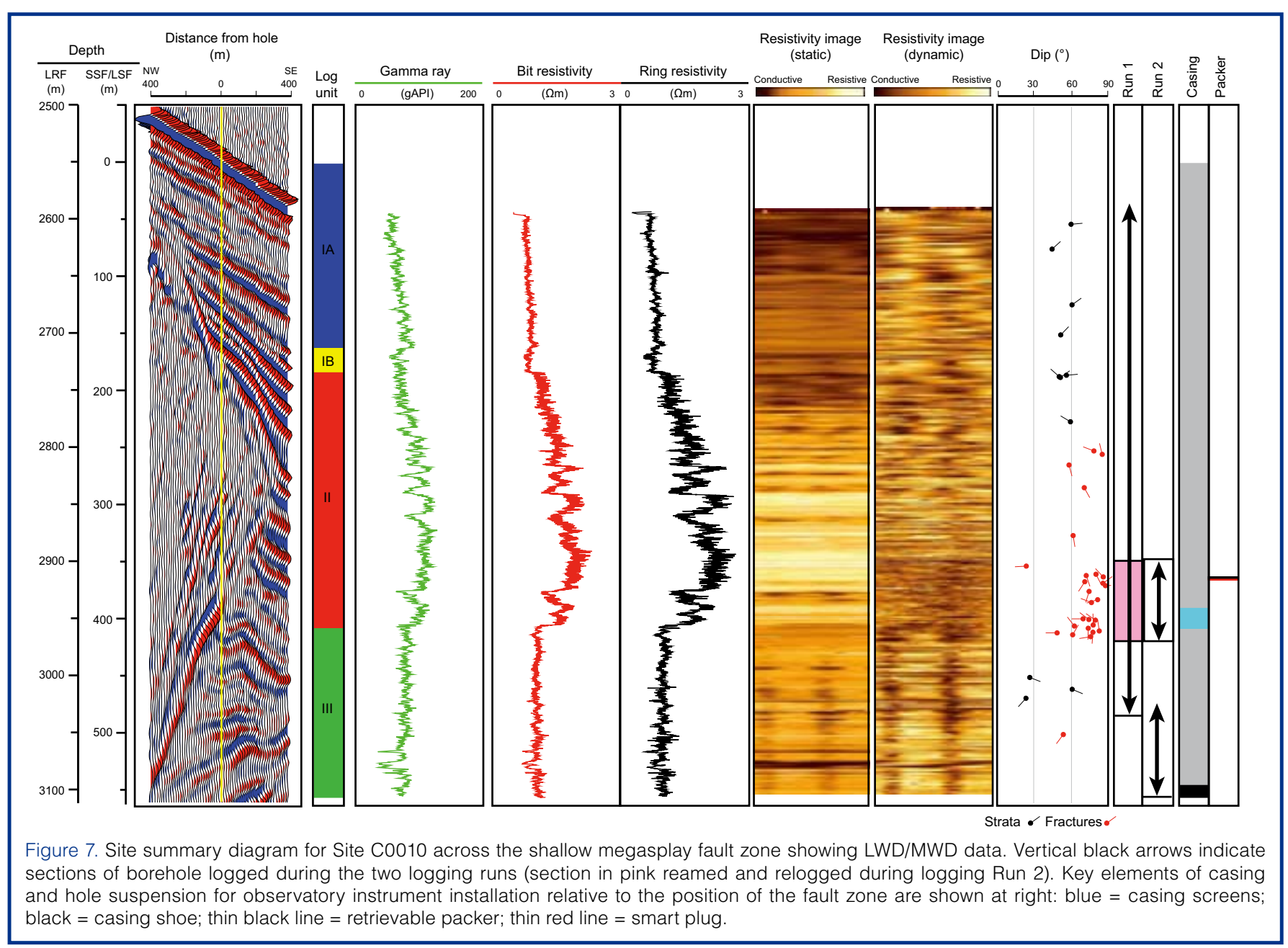




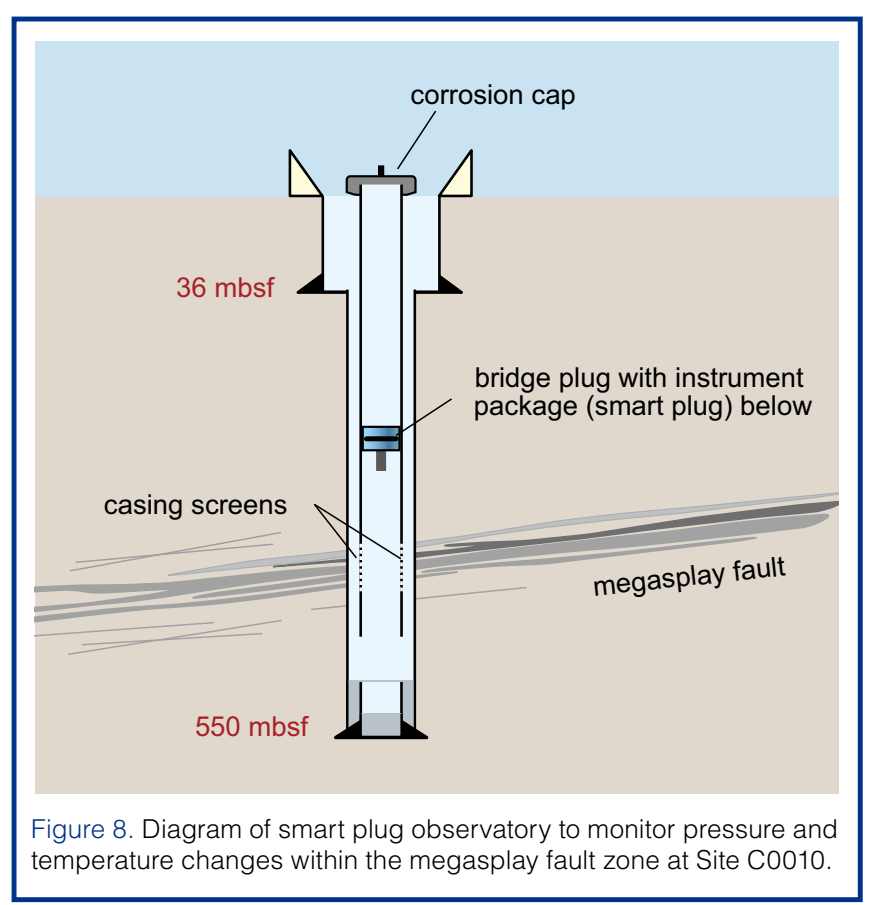

Site C0004 (Kinoshita et al., 2009b) —slope deposits (Unit I, 0-183 mbsf); thrust wedge/hanging wall of the megasplay fault zone (Unit II, 183-407 mbsf); and overridden slope deposits/footwall of the megasplay fault zone (Unit III, 407 mbsf to TD). At Site C0010, the thrust wedge has lower gamma ray and higher resistivity values than its equivalent at Site C0004. These values suggest higher clay content and potentially increased compaction in the Site C0010 thrust wedge. Porosity estimated from resistivity log values indicates reduced porosity within the $\mathrm{C} 0010$ thrust wedge, although low resistivity may in part result from high clay content. Marked reductions in resistivity across the megasplay fault zone correspond to a negative (or inverted) polarity seismic reflector, suggesting reductions in velocity and density into the underthrust/overridden slope deposits of the footwall. At nearby Site $\mathrm{C} 0004$, the equivalent reflector is positive polarity, emphasizing that differences in properties, primarily of the hanging wall thrust wedge, can occur over a very short distance within the forearc. These differences may originate from contrasts in original composition or in degree of exhumation along the thrust fault.

Ship heave during logging resulted in variable quality of resistivity image data for structural interpretation; however, analysis of orientations of borehole breakouts revealed an orientation of horizontal maximum stress of NW-SE (Fig. 6). This orientation is similar to that measured at other sites across the prism during NanTroSEIZE Stage 1 and similar to the orientation at Site C0009 in the central forearc basin. An abrupt downhole change in breakout orientation across the megasplay fault zone at Site C0010 is consistent with a sharp mechanical discontinuity at the fault zone (Barton and Zoback, 1994); such a change is not observed at nearby Site C0004, where the megasplay is defined as a broad 50-m-thick fault-bounded package. Minor faults are concentrated around the thrust zone, as might be expected.
Two sensor dummy runs were conducted using a strainmeter, seismometer, temperature loggers, and an accelerometer-tiltmeter (Fig. 3C) to test the degree of vibration and shock associated with running the instrument package through the water column and reentering the borehole. Unfortunately, during the first run the seismometer and strainmeter became detached and lost due to strong vibrations of the drill pipe in a high current velocity area; however, acceleration, tilt, and temperature data were recorded within the water column. The second run (including a dummy strainmeter with identical dimensions) attempted to test reentry conditions at the wellhead. During both runs, vibrations in the water column resulting from high current velocity were significantly greater than expected, and these results will be critical for modifying future installations of observatory instruments. On a more positive note, a temporary single observatory "smart plug" was successfully installed in the borehole. Screened casing intervals and a retrievable packer will isolate the megasplay fault zone (Figs. 7 and 8) and allow measurements of pressure (referenced to hydrostatic pressure) and temperature to be taken regularly at one-minute intervals over a period of a few years before the instrument package is recovered during future NanTroSEIZE operations.

\section{Key Scientific and Technical Results and Future Work}

Data from Expedition 319 and previous NanTroSEIZE drill sites can now be integrated to provide constraints on present-day stress orientation and magnitude across the forearc; they can also be compared with past records of deformation at a range of scales (from core to seismic), incorporating, for the first time, measurements of in situ stress magnitude. The emerging picture of stress conditions (Kinoshita et al., 2009a and 2009b; Tobin et al., 2009) is one in which maximum horizontal stress is slightly oblique to the plate convergence across the prism and the inner forearc basin, but deviates from this trend in the outer forearc basin where margin perpendicular extension dominates (Fig. 6). In situ stress magnitude at Site C0009 suggests that a normal or strike-slip faulting regime dominates today. Normal faults are observed in reflection data of nearby parts of the basin, but fault orientations from resistivity images are inconsistent with these present-day stress measurements and likely represent an earlier phase of deformation and evolution of stress regimes in the hanging wall of the plate boundary fault.

For the first time, in situ hydrological properties of sediments and rocks have been obtained for scientific analysis. These properties (e.g., formation pore pressure and permeability) are critical parameters for understanding the role of fluids in deformation of the forearc and will ultimately be important for determining the role of fluids in fault development and in seismogenic behavior. Properties and behavior can be inferred from core samples and logs, but only direct 
measurements at depth provide in situ properties where these processes are taking place.

Performing riser drilling for the first time in IODP presented a range of operational and analytical challenges. Experiences from this expedition will be valuable for future riser drilling operations within scientific ocean drilling. New methods of analyzing cuttings were developed, and the validity of specific measurements on cuttings was tested. Methods of integrating cores, cuttings data, and log data were also developed to provide the most scientifically realistic interpretation of downhole geological (including lithology, biostratigraphy, structure) and physical properties, particularly important for future deep boreholes where continuous coring will not be feasible. Existing methods for drill mud gas analysis established for continental drilling were also applied successfully to drilling in a marine environment.

Future work will focus on the following: a) results made possible by these new techniques, b) continued post-expedition shore-based laboratory and analytical study of samples, and c) integration of the drilling results from Expedition 319 with existing results across the broader forearc from NanTroSEIZE Stage 1 and with non-drilling datasets, such as 3-D seismic reflection data. Collectively, these will provide the context of regional forearc structure including that of the deeper seismogenic plate boundary.

\section{Acknowledgements}

We thank the crew of the D/V Chikyu and all drilling operations and related personnel, particularly the efforts of Marine Works Japan laboratory technicians and all Mantle Quest Japan onboard personnel who worked diligently to ensure the success of Expedition 319.

\section{IODP Expedition 319 Scientists}

David Boutt, David Buchs, Christophe Buret, Marianne Conin, Deniz Cukur, Mai-Linh Doan, Natalia Efimenko, Peter Flemings, Nicholas Hayman, Keika Horiguchi, Gary Huftile, Takatoshi Ito, Shijun Jiang, Koji Kameo, Yasuyuki Kano, Juniyo Kawabata, Kazuya Kitada, Achim Kopf, Weiren Lin, J. Casey Moore, Anja Schleicher, Roland von Huene, and Thomas Wiersberg

\section{References}

Ando, M., 1975. Source mechanisms and tectonic significance of historical earthquakes along the Nankai trough, Japan. Tectonophysics, 27:119-140.

Araki, E., Byrne, T., McNeill, L., Saffer, D., Eguchi, N., Takahashi, K., and Toczko, S., 2009. NanTroSEIZE Stage 2: NanTroSEIZE riser/riserless observatory. IODP Sci. Prosp., 319. doi:10.2204/iodp.sp.319.2009.
Ashi, J., Lallemant, S., Masago, H., and the Expedition 315 Scientists, 2009. Expedition 315 summary. In Kinoshita, M., Tobin, H., Ashi, J., Kimura, G., Lallemant, S., Screaton, E.J., Curewitz, D., Masago, H., Moe, K.T., and the Expedition 314/315/316 Scientists, Proc. IODP, 314/315/316: Washington, DC (Integrated Ocean Drilling Program Management International, Inc.). doi:10.2204/iodp.proc.314315316.121. 2009

Bangs, N.L.B., Moore, G.F., Gulick, S.P.S., Pangborn, E.M., Tobin, H.J., Kuramoto, S., and Taira, A., 2009. Broad, weak regions of the Nankai megathrust and implications for shallow coseismic slip. Earth Planet. Sci. Lett., 284:44-49.

Barton, C.E., and Zoback, M.D., 1994. Stress perturbations associated with active faults penetrated by boreholes: possible evidence for near-complete stress drop and a new technique for stress magnitude measurement. J. Geophys. Res., 99:9379-9390, doi:10.1029/ 93JB03359.

Byrne, T., Lin, W., Tsutsumi, A., Yamamoto, Y., Lewis, J.C., Kanagawa, K., Kitamura, Y., Yamaguchi, A., and Kimura, G., 2009. Anelastic strain recovery reveals extension across SW Japan subduction zone. Geophys. Res. Lett., 36:L23310, doi:10.1029/2009GL040749.

Heki, K., 2007. Secular, transient and seasonal crustal movements in Japan from a dense GPS array: implications for plate dynamics in convergent boundaries. In Dixon, T., and Moore, C. (Eds.), The Seismogenic Zone of Subduction Thrust Faults: New York (Columbia University Press), 512-539.

Hino, R., Kinoshita, M., Araki, E., Byrne, T.B., McNeill, L.C., Saffer, D.M., Eguchi, N.O., Takahashi, K., and Toczko, S., 2009. Vertical seismic profiling at riser drilling site in the rupture area of the 1944 Tonankai earthquake, Japan. Eos Trans. $A G U, 90$ (52), Fall Meet. Suppl., Abstract T12A-04.

Ienaga, M., McNeill, L.C., Mikada, H., Saito, S., Goldberg, D., and Moore, J.C., 2006. Borehole image analysis of the Nankai accretionary wedge, ODP Leg 196: structural and stress studies. Tectonophysics, 426:207-220.

Ito, Y., Obara, K., Shiomi, K., Sekine, S., and Hirose, H., 2007. Slow earthquakes coincident with episodic tremors and slow slip events. Science, 315:503-506. doi:10.1126/science. 1134454 .

Kikuchi, M., Nakamura, M., and Yoshikawa, K., 2003. Source rupture processes of the 1944 Tonankai earthquake and the 1945 Mikawa earthquake derived from low-gain seismograms. Earth Planets Space, 55:159-172.

Kimura, G., Screaton, E.J., Curewitz, D., and the Expedition 316 Scientists, 2009. Expedition 316 summary. In Kinoshita, M., Tobin, H., Ashi, J., Kimura, G., Lallemant, S., Screaton, E.J., Curewitz, D., Masago, H., Moe, K.T., and the Expedition 314/315/316 Scientists, Proc. IODP, 314/315/316: Washington, DC (Integrated Ocean Drilling Program Management International, Inc.). doi:10.2204/iodp. proc.314315316.131.2009

Kinoshita, M., Tobin, H., Moe, K.T., and the Expedition 314 Scientists, 2009a. Expedition 314 summary. In Kinoshita, M., Tobin, H., Ashi, J., Kimura, G., Lallemant, S., Screaton, E.J., Curewitz, D., Masago, H., Moe, K.T., and the Expedition 314/315/316 Scientists, Proc. IODP, 314/315/316: Washington, DC (Integrated Ocean Drilling Program Management International, Inc.). doi:10.2204/iodp.proc. 


\subsubsection{9}

Kinoshita, M., Tobin, H., Ashi, J., Kimura, G., Lallemant, S., Screaton, E.J., Curewitz, D., Masago, H., Moe, K.T., and the Expedition 314/315/316 Scientists, 2009b. NantroSEIZE Stage 1: investigations of seismogenesis, Nankai Trough, Japan, Proc. IODP, 314/315/316: Washington, DC (Integrated Ocean Drilling Program Management International, Inc.), doi: 10.2204/iodp.proc.314315316.111.2009.

Lin, W., Doan, M.-L., Moore, J.C., McNeill, L.C.,et al., 2010. Presentday principal horizontal stress orientations in the Kumano forearc basin of the southwest Japan subduction zone determined from IODP NanTroSEIZE drilling Site C0009. Geophys. Res. Lett., 37, doi:10.1029/2010GL043158.

McNeill, L.C., Ienaga, M., Tobin, H., Saito, S., Goldberg, D., Moore, J.C., and Mikada, H., 2004. Deformation and in situ stress in the Nankai accretionary prism from resistivity-at-bit images, ODP Leg 196. Geophys. Res. Lett., 31:L02602, doi:10.1029/2003GL018799.

Miyazaki, S., and Heki, K., 2001. Crustal velocity field of southwest Japan: subduction and arc-arc collision. J. Geophys. Res., 106:4305-4326, doi:10.1029/2000JB900312.

Moore, G.F., Bangs, N.L., Taira, A., Kuramoto, S., Pangborn, E., and Tobin, H.J., 2007. Three-dimensional splay fault geometry and implications for tsunami generation. Science, 318:1128-1131. doi:10.1126/science.1147195.

Moore, G.F., Park, J.O., Bangs, N.L., Gulick, S.P., Tobin, H.J., Nakamura, Y., Sato, S., Tsuji, T., Yoro, T., Tanaka, H., Uraki, S., Kido, Y., Sanada, Y., Kuramoto, S., and Taira, A., 2009. In Kinoshita, M., Tobin, H., Ashi, J., Kimura, G., Lallement, S., Screaton, E.J., Curewitz, D., Masago, H., Moe, K.T., and the Expedition 314/315/316 Scientists. Structural and seismic sstratigraphic framework of the NanTroSEIZE Stage 1 transect, Proc. IODP, 314/315/316, Washington, DC (Integrated Ocean Drilling Program Management International, Inc.). doi:10.2204/ iodp.proc.314315316. 102.2009 .

Obara, K., and Ito, Y., 2005. Very low frequency earthquakes excited by the 2004 off the Kii peninsula earthquakes: a dynamic deformation process in the large accretionary prism. Earth Planets Space, 57:321-326.

Park, J.-O., Fujie, G., Wijerathne, L., Hori, T., Kodaira, S., Fukao, Y., Moore, G.F., Bangs, N.L., Kuramoto, S., and Taira, A., 2010. A low-velocity zone with weak reflectivity along the Nankai subduction zone. Geology, 38:283-286.

Saffer, D., McNeill, L., Araki, E., Byrne, T., Eguchi, N., Toczko, S., Takahashi, K., and the Expedition 319 Scientists, 2009. NanTroSEIZE Stage 2: NanTroSEIZE riser/riserless observatory. IODP Prel. Rept., 319. doi:10.2204/iodp.pr.319.2009

Saffer, D., McNeill, L., Araki, E., Byrne, T., Eguchi, N., Toczko, S., Takahashi, K., and the Expedition 319 Scientists, 2010. Proc. IODP, 319: Washington, DC (Integrated Ocean Drilling Program Management International, Inc.).

Seno, T., Stein, S., and Gripp, A.E., 1993. A model for the motion of the Philippine Sea Plate consistent with NUVEL-1 and geological data. J. Geophys. Res., 98(B10):17,941-17,948. doi:10.1029/93JB00782.

Tobin, H.J., and Kinoshita, M., 2006. NanTroSEIZE: the IODP Nankai Trough Seismogenic Zone Experiment. Sci. Drill., 2:23-27. doi:10.2204/iodp.sd.2.06.2006.
Tobin, H., Kinoshita, M., Ashi, J., Lallemant, S., Kimura, G., Screaton, E.J., Moe, K.T., Masago, H., Curewitz, D., and the Expedition 314/315/316 Scientists, 2009. NanTroSEIZE Stage 1 expeditions: introduction and synthesis of key results. In Kinoshita, M., Tobin, H., Ashi, J., Kimura, G., Lallemant, S., Screaton, E.J., Curewitz, D., Masago, H., Moe, K.T., and the Expedition 314/315/316 Scientists, Proc. IODP, 314/315/316: Washington, DC (Integrated Ocean Drilling Program Management International, Inc.). doi:10.2204/iodp. proc.314315316.111.2009

Underwood, M.B., Saito, S., Kubo, Y., and the Expedition 322 Scientists, 2009. NanTroSEIZE Stage 2: subduction inputs. IODP Prel. Rept., 322. doi:10.2204/iodp.pr.322.2009.

Underwood, M.B., Saito, S., Kubo, Y., and the IODP Expedition 322 Scientists, 2010. IODP Expedition 322 drills two sites to document inputs to the Nankai Trough Subduction Zone, Sci. Drill. 10:14-25, doi: 10.2204/iodp.sd.10.02.2010.

\section{Authors}

Lisa McNeill, School of Ocean and Earth Science, National Oceanography Centre, Southampton, University of Southampton, Southampton, SO14 3ZH, UK, lcmn@noc. soton.ac.uk.

Demian Saffer, The Pennsylvania State University, University Park, PA 16802, U.S.A.

Tim Byrne, Center for Integrative Geosciences, University of Connecticut, Storrs, CT 06269, U.S.A.

Eiichiro Araki, Earthquake and Tsunami Research Project for Disaster Prevention, Japan Agency for Marine-Earth Science and Technology (JAMSTEC), Kanagawa 237-0061, Japan.

Sean Toczko, Nobu Eguchi, and Kyoma Takahashi, Center for Deep Earth Exploration (CDEX), Japan Agency for Marine-Earth Science and Technology (JAMSTEC), Kanagawa 237-0061, Japan.

and the IODP Expedition 319 Scientists

\section{Related Web Link}

http://www.jamstec.go.jp/jamstec-e/maritec/donet/

\section{Photo Credits}

Fig. 3 A. by Lisa McNeill, University of Southhampton Fig.3 B and C. by CDEX-Jamstec 